Saudi Journal of Humanities and Social Sciences

Abbreviated Key Title: Saudi J Humanities Soc Sci

ISSN 2415-6256 (Print) | ISSN 2415-6248 (Online)

Scholars Middle East Publishers, Dubai, United Arab Emirates

Journal homepage: https://saudijournals.com/sjhss

Review Article

\title{
Fear: Traumitising the Human Mind
}

\author{
Dr. Avdhesh S. Jha*
}

Faculty, EDI of India, Gandhinagar, Gujarat, India

DOI: $10.36348 /$ sjhss.2020.v05i09.005 $\quad$ | Received: 13.09 .2020 | Accepted: 20.09.2020 | Published: 25.09 .2020

*Corresponding author: Dr. Avdhesh S. Jha

\section{Abstract}

The furious and grave COVID-19 pandemic may look to be a serious matter as of now but along with it has entered more furious, more grave and most dangerous virus of misinformation which spreads without any control across the globe within no time and impacts the world negatively misleading each one with the differences that creates distrust towards each other and turns each of them more selfish, lonely and inhuman. Like the corona epidemic termed as pandemic; the fastest spread of misinformation, maybe termed as the misfodemic turned most dreary and scary. Unaware of the facts and its cure, the people kept loitering with the false information being surrounded with its spread and reach troubling themselves with nothing, for nothing. The power of social sites, science and technology was much required here to let truth prevail and the fake or the false to perish.

Keywords: Fear, Pandemic, epidemic, corona, Covid 19, Human.

Copyright @ 2020: This is an open-access article distributed under the terms of the Creative Commons Attribution license which permits unrestricted use, distribution, and reproduction in any medium for non-commercial use (NonCommercial, or CC-BY-NC) provided the original author and source are credited.

\section{INTRODUCTION}

In this era of science and technology, media is the backbone of the society. Media is a source of guide and information. And thus, it has the responsibility to validate the news before sharing. Because of the popular social sites keeping the people busy to share the information, today most of the people have turned a media man but hardly have any sense of duty and responsibility [1]. The competition amongst the newsmongers to be the first one to share the news and picture created a chaos as the messages were misrepresented and mis-interpreted. These newsmongers created a chaos by sharing the news without any facts and validation which created misfodemic. Misfodemic here means misinformation epidemic. The reporting and repetition of the same news created a terror and trauma amongst the people who kept updating themselves with the virus and its impact on the society [2]. These were the one to consider everyone suffering from corona and looked upon them with hatred. A little irresponsible behaviour by the newsmongers of the social sites and some media created several problems to the innocent people from the community. Not restricting the misfodemic to the community, it created competition among the rulers and ministers to use the social sites and news channels to post themselves as the first one to take steps. It was pity politicians took this tragic event as opportunity of popularity. Social sites were the one to add to the misfodemic which further added to the mis-interpretations and forced people to take the steps which were strongly prohibited [3]. The pandemic thus presented a huge virus infecting the people at large with distrust and thus promoting the uncurable misfodemic at the cost of trust merely for small and temporal gains against humanity [4].

\section{PROS AND CONS OF PANDEMIC}

The pandemic questioned the medical and psychosomane (psychological, social and humane) readiness of the countries to face such a situation. It threatened and challenged the developed countries boasting about GDP with the best infrastructure, instructional facilities, human resources, industrial development and technology that were hardly able to cope up with this pandemic. It prompted the countries to assess their health and medical facilities and its related infrastructure [5]. With COVID 19 were posited several restrictions as a precautionary step. Whereas some self-locked themselves, others were forced by the system to lock down and follow the lock out. Indeed, this imposition was a terror for the people. Several were panicked with lock down whereas some behaved wise. Unfortunately, people took a long time to understand why system forced the closure of schools and colleges for students. Although this step was not well understood by the managers but it created new opportunities for many which initiated the application of technology to education. With several threats as such ability to bear 
the stress of lock down and its control; the stress of the meetings about the economic betterment of the organisation; the unending debate about the effectiveness of the online or virtual classes; expectation of the authorities from the teachers to prepare the case study, research papers and innovative lessons etc.; poor mental health of teachers, employees and people with different SES; miscommunication; stress of fake news on popular social sites; politicisation of the news, creating differences and polarisation of society; the trauma of the daily wage workers and its possible causes and outcome; the mindset of the people towards other fellow beings; stress of being human to anyone coughing and sneezing; the stress of ability of being human at the idea of risking life; the stress of the idea of our development with respect to our own health etc. posited a lot to the society and its balance turning it more unbalanced. Such an unbalance urges for rethinking about the luxury, leisure, high GDP, technological development and best infrastructure as indicators of development. It further seeks clarification if even the developed countries have the capability to safeguard its human health and societal health to this pandemic [6].

For most of the employee - the backbone of the organisation; the debate about the organisational heads caring for their organisational economic wellbeing vs. those caring their employees' health arose. The terror of reporting twice by the employees even in teaching field along with the proof of work done was a horrifying state. The debate about fake news, the social sites abuse, politicisation of news, self-publicity at the cost of corona terror, cheap and mean politics, declining humanity were very common but just remained unanswered. Such situation asks the society to assess if humanity prevails as well if economy is the only need for human development? It also questions the physical, social, mental, emotional, aesthetical or spiritual health of the societal members and asks to check the same when we are self-locked. With increasing terror and trauma of the situation even though humanity without fear of economic consequences was emphasized, its pity that the societal institutions were busy following their protocols selfishly, some of which affected and impacted the name and fame of country badly. Whereas the situation was an alarming bell about poor medical infrastructure and facilities and lack of preparedness of the countries towards this situation this pandemic proved that technology (although not preferred by most) can also be an option to education [7].

Most of the countries have their own history of freedom. Yet we have failed to understand the importance of freedom and so still we are not free. We are the slaves of prevailing inequality, differences of color, race, religion, gender, power, capitalism, technological development etc. Each minute some powerful is killing the humanity and so we are still not free. The tiny corona challenging the mankind has proven its might now and all the mankind is suffering. The race of proving the worth with materialistic development initiated by some ignorant is now the race of the world because of insecurity amongst the others.

Any country is the land of people of passionate love, and faith. Today technological advancement is not a major issue for any country rather expansion and its reach to all, is important. Rather than Bullet Train Project the humanitarian projects are important. Rather than the investment in high speed train the countries need the investment for loving and caring heart and brain. The issues for upliftment of declining humanity, life and its safety are important. The small corona posited a lot threat and shackled the world and all its aspect. It questioned the developing countries and the mankind about its so-called development and challenged the readiness of the world for any such sudden event and cause. Infact it has awakened the world. It rests up to us, how we take it. The attraction and run for creation of tallest statues as wonders of world are just becoming a tourist sight and will remain meaningless with pictures in the mobile phones. The need is valuing the value. The nations can just boast of its development on the basis of its economy and GDP but for the fact this doesn't indicate the real development. The development lies not in giving the concept of Global village but lies in turning this concept practical and real. It should not remain a concept to study but be converted to real situation to feel and enjoy. All we need to do is to manufacture humanity, to produce and consume humanity, develop equality. To reach Mars is not tough but to add and prevail humanity and be prepared for any such situation is real development.

The furious and grave COVID-19 pandemic may look to be a serious matter as of now but along with it has entered more furious, more grave and most dangerous virus of misinformation which spreads without any control across the globe within no time and impacts the world negatively misleading each one with the differences that creates distrust towards each other and turns each of them more selfish, lonely and inhuman. Like the corona epidemic termed as pandemic; the fastest spread of misinformation, maybe termed as the misfodemic turned most dreary and scary. Unaware of the facts and its cure, the people kept loitering with the false information being surrounded with its spread and reach troubling themselves with nothing, for nothing. The power of social sites, science and technology was much required here to let truth prevail and the fake or the false to perish. Whether physical, social, mental, aesthetical, economical or spiritual health of the human, this misfodemic with its ease of reach and access to all human, endangered each type of human health and harmed it badly creating distrust all around and thus infected the society. Thrilled falsehoods full of wild conspiracy towards a caste, community, society, state, nation and other 
countries are the waves that fill in the air to damage the mind and thought process of all those inhaling it whether knowingly or unknowingly. Media and people say it's the videos that getting viral but for the fact it's the spurring abundant envy, jealousy and hatred spreading and getting viral and infecting the people mentally with such a strong impact as to infect several generations. This is the time science should be awakened strongly, technology supported social sites should spur with dissemination of facts infecting the human with lessons of love and humanity, and most importantly the developer of the viruses of the differences be punished without any mercy whether a human or a politician!

The pandemic impacted the human mind severely. Although the related decisions were late but there is no denial that the decisions were taken in good faith. But the decisions proved to be vague and fatal for lacs of people causing huge irreparable loss of lives and contamination of human mind. For sure, this pandemic will end soon but the consequences might be very harsh and tough. Even after the end of this pandemic, for a long time, it would be difficult for the parents to send their ward to school. There are chances that many of them will change their idea of lavishness and will restrict their needs. It may lead to abhorring the brands, less outing, less show off which may affect the economy badly. Socialism may also be affected and impacted and people may choose to limit themselves only to a few by restricting the size of family, relatives and friends. Although human has the benefit of boon of forgetfulness but till the individuals forget it will take not less than a year to turn the things normal and socialism is such which once affected is likely to create the walls permanently. Precautions were must but precautionary measures should have been strong enough to prevent the attack on the livelihood of the hard-working people because they are the equal member of society and their progress or regress equally affects the society. The related strong messages of imposed control, measures and prevention must have been delivered softly and smoothly with caution, assurance and fulfillment of basic needs. Necessary care and precaution turns must to prevent infecting the innocent. Sooner or later, the vaccine for this virus will exist and maybe one or two doses of this vaccine will develop the stamina to resist the disease but the virus of distrust created by the misfodemic cannot be healed, cured or vaccinated by any medicine. The only way is preserving the trust, developing the trust and transmitting the trust for one and all irrespective of the political, economic, individual selfish gains whether for power or position of an individual or the country. This trust should exist within and between the individual, communities, states and countries. It's only this trust that can add to humanity and turn world a true global village. With a hope that trust prevails and humanity hails, I am sure each home will be quarantined with COVID 19 but I hope and wait for the world where each home and mind are quarantined with the fastest spreading misfodemic that creates differences amongst the human and endangers the existence of humanity on this beautiful paradise.

Whether the tiny corona or the fear of lack of preparedness of the developed countries, their arrogance, casual undermining of the situation and their selfish motto created the trauma remains to be checked. With a hope of best for the mankind, appreciating and paying tribute to all those who have supported this fight against corona directly or indirectly, I am sure this article will enlighten us with the real idea of development which starts with the health whether physical, social, mental, emotional, aesthetical or spiritual and ends with humanity.

\section{REFERENCES}

1. Chandler, R. (2001). Crisis management: Does your team have the right members? Safety Management, 458, 1-3.

2. Coombs, W. (2007). Ongoing crisis communication: Planning, managing and responding ( $2^{\text {nd }}$ ed.). Thousand Oaks: Sage.

3. Hart, P., Heyse, L., \& Boin, A. (2001). New trends in crisis management practice and crisis management research: Setting the Agenda. Journal of Contingencies and Crisis Management, 9(4), 181-199. doi:10.1111/1468-5973.00168

4. Jha, Avdhesh S. (2011). Research Methodology, New Delhi: APH Publishing Corporation

5. Jha, Avdhesh S. (2011). Educational Research, Germany: VDM Publications

6. Jha, Avdhesh S. (2014). Social Research Methods, New Delhi: McGraw Hill BookMaslow, A. H. (1987). Motivation and personality (3rd ed.). Delhi, India: Pearson Education.

7. Pearson, C. M., \& Clair, J. A. (1998). Reframing crisis management. Academy of Management Review, 23(1), 59-78. 